\title{
Research into Shanghai Women's Fashion Clothes in Minguo Era (1912-1949)
}

\author{
Zhaoqing Li \\ Fuzhou University \\ Fuzhou, China
}

\begin{abstract}
Women's fashion clothes in Minguo era were produced and developed in certain context, integrating Chinese and western culture as well as ancient and modern ones. Then it shaped Shanghai-style clothes with independent, stable and mature features. At that time, Shanghai was in the center of fashion in Asia, and women's fashion clothes came into a separate industry. Women's fashion clothes in Shanghai during that period focused on the beauty of women's body figure with various forms, decorated craftsmanship, innovative power, cultural elements and profound influence. In general, Shanghai women's fashion clothes in Minguo era reflect the history of fashion and mirror the development of Minguo culture.
\end{abstract} clothes

Keywords-Minguo era; Shanghai; fashion; women's

\section{INTRODUCTION}

In terms of definition, Minguo era refers to the Repubic of China from 1912 to 1949. Shanghai in early Minguo era was a county and became a special municipal city after 1927. Xin Zhuang County which was in Jiangsu Province was categorized into Shanghai. After 1930, Shanghai was officially instituted as a municipal city. Moreover, women's clothes refer to all the dressings for women, opposite to men's clothes and excluding female children's clothes. Shanghai-style was originally seen in painting and then extended to various aspects in culture and arts which was finally regarded as a symbol of Shanghai reginal culture.

\section{1. ThE CULTURAL BACKGROUND OF WOMEN'S FASHION CLOTHES IN MINGUO ERA}

The period of Minguo Era (1911-1949), which was a vital time in the integration of Chinese and western clothes cultures as well as the integration of ancient and modern clothes cultures in Chinese clothes history. In this time, China witnessed a dynamic and multi-styles period; this period can be crowned as a model in the history of modern Chinese clothes. It embraced all sorts of advantages, great innovations, and various styles. It also had some breakthroughs in traditional Chinese clothes and largely enriched the nature and extension of Chinese clothes.

Since its opening-up in 1843, Shanghai developed from a tiny village into an international metropolis due to its unique advantages in geography. Shanghai was the center of the exchanges in economy and culture and the leader of the fashion of Chinese clothes. The fashionable dressing of Shanghai people in that modernizing period reflected the culture and esthetic ideology of the society. Therefore, it is the expression of Shanghai's urban culture and values.

Given the context that the salvation of state in China of that time was in great demand, the liberation movement of women which was in pursuit of defending the state by strengthening its people was under way in a large scale. Especially after the victory of Northern Expedition in 1927, Chinese women gained the equal political right as men. Due to their independence in economy, freedom in marriage, equality in education, and enlightenment in culture, women's liberation movement developed fast and spread to other places. These are all reflected in women's clothes.

The designers then, based on the sense of brand as well as fashion in women's mind, made a series of clothes after an examination of the culture, art and demand. Therefore, the style of clothes always complies with the ideology of that time; in fact, the clothes are sound reflection of the spiritual and cultural elements in society.

\section{INFLUENTIAL FACTORS OF WOMEN'S CLOTHES IN SHANGHAI IN MingUO ERA}

There are both internal and external factors which influence women's clothes in Minguo Era. The internal factors are related to the development of the industry, while the external ones the cultural environment, which propelled the clothes then. The former include the development of fashion designers, tailor teachers, fashion companies, sewing machinery, textile factories, and other related industries. For instance, it was during this period that the earliest clothes designers in Shanghai appeared. They were painters of Yuefen-pai (a card with a picture on one side and a mini calendar on the other), cartoon etc. Famous designers include Zhen Mantuo, Hang Zhiying, Xie Zhiguang, Li Mubai, Ye Qianyu, Wan Laiming etc. The clothes designed were also printed on Yue-fen-pai, newspapers or magazines, displaying the flourishing fashion clothes of women.

The external factors, on the other hand, include fashion people (e.g. migrants, concession staff, people studying abroad), places of entertainment (e.g. KTV, theatres, brothels), media (e.g. books, newspapers, broadcast), political ideology (e.g. regulations in mourning apparel, the 
New Life Movement, the Natural Breast Movement, the Anti-Japanese and National Salvation Movement), life style (e.g. outdoor sports, human aesthetic, social pleasure), arts and literature (e.g. dramas, movies, novels, paintings etc). Under the influence of these factors, women's clothes became more and more gorgeous.

\section{THE STYLE CATEgORY OF WOMEN's ClOTHES IN SHANGHAI IN MINGUO ERA}

Women's clothes in Minguo Era can be categorized into three styles: Chinese, Western, and Chinese-Western styles. Clothes of the Chinese style were designed according to conventional culture and rules. And they were generally based on the style in the clothes regulations issued in 1912 and 1929.

Clothes of the Western style were the stylish dress in Western society at that time. They were further divided into three types: dress, jacket-skirt suit, and jacket-trousers suit. Under the large influence of western culture, women's clothes in Shanghai were generally westernized during the late period of Minguo Era.

And clothes of the Chinese-Western style were the combination of both cultures, designed by tailors from the western countries. They became the main trend because of their beauty and elaborateness, with the western style and the Chinese convention of decoration. For instance, a Cheongsam of the Chinese-Western style followed the western dyapiag. But the decoration of details such as its collar and sleeve would be in the Chinese style.

The fashion clothes of women were either made into one piece or composed of two parts. Different kinds include the traditional shirt, padded jacket, trousers and dress, the western costume, underwear, swimming clothes, fur coat, knitted sweater, windbreaker, dancing clothes, silk stockings, and high-heeled shoes, as well as the Chinese-western jacket-skirt suit and cheong-sam. These classic kinds reached the peak of the age.

The women's clothes of this period reflect the multicultural society and the essence of the urban culture of Shanghai. Meanwhile, this unique culture of combination and fashion further influenced the style of dressing as well as living, which gradually became the gene of Shanghai women and Shanghai culture. Generation after generation, we can still feel it in the streets of the city at present.

\section{DEVEloping Stages OF SHANGHAi WOMEN's FASHION CLOTHES IN MINGUO ERA}

From the perspective of fashion leader and consumer, most of women's fashion clothes were for upper-class or wealthy women, including film stars, socialites, female students, female dancing stars and prostitutes. Their clothes were imitated by the public at that time and influenced the general trends. Therefore, their new style imposed impact on trends and women's fashion clothes in Minguo era kept bring forth the fresh.

\section{A. Shanghai Women's Clothes in the 1910s}

In the 1910s, Shanghai women's clothes were mostly jackets, blouses and trousers as well as innovative new-style clothes. Moreover, some women were dressed in male clothes in order to stress the equality between men and women. At that time, Shanghai women's fashion clothes were mainly in traditional Chinese style even in daily life, which can be seen in lots of historical materials.

In addition, various thoughts, Chinese and western, traditional and modern, all coexist in Shanghai. Clothes which were long imbedded in ideology had been manifested in unique and new forms. Also, abnormal and exaggerated clothes were quite common; for example, prostitutes put bulbs on their clothes to attract people. As the lay Buddhist Jiangshui commented, "clothes were shipped from overseas; once the boxes were unloaded, people who heard of the news all came to purchase. All the products could be sold out within three days. As for the clothes, the sleeves were too short to cover arms and the cuff was too loose. The trousers were too short to reach the knees and the trouser legs were too big as famer's clothes. And, silk stockings on legs made the skin partly visible. Recently, clothes underwent another huge change: trouser legs were getting bigger and longer; jackets were short at waist."

\section{B. Shanghai Women's Clothes in the 1920s}

Shanghai women's clothes in the 1920s were mostly new-style ones, cheongsam, western coat and dress. Traditional Chinese clothes were adapted with western elements.

For example, we can often see in historical materials that women dressed in Chinese cheongsam usually wear watches with black leather chain and western wool coat with a western leather bag in hand. Such kind of dressing style was very popular in the 1920 s. It contributes to the integration of Chinese and western elements in Shanghai women's clothes in Minguo era and brings new features.

\section{Shanghai Women's Clothes in the 1930s}

At that time, fashion concept had been around in Shanghai people's mind. For example, debates over fashion clothes were common in magazines or newspapers. Fashion was translated as fan hsin and modern was rendered as mo teng. Clothes were defined and debated a lot. For instance, Sha Enfu defined fashion clothes, in 1931 at New Family magazine, as "that changes with time and place, and most popular at that time and that place."

In the 1930s, Shanghai women's clothes were mostly improved cheongsam, western coat and dress. People had great passion in wearing and improving cheongsam for beautifying women's body. Along with the popularity and design of Minguo clothes, lots of women in Shanghai made full use of their talents and contributed to the innovation and improvement of women clothes in Minguo era. For example, many women in Shanghai spent their free time in learning knitting and sewing from experts. 
Women's clothes at that time boasted clear and mature features, striking and rich popular styles. Sometimes, they even learnt from the latest fashion in Paris, the centre of the world fashion. Trends in fashion clothes always changed over seasons, months and even days. During that period, fashion manufactures in Shanghai kept producing the latest style; women consumers invested a lot in purchasing these fashion clothes since they were shamed of being outdated in dressing. All these were conductive to the fast development of knitted women's clothes in the 1930s in Shanghai.

\section{Shanghai Women's Clothes in the 1940s}

Shanghai Women's clothes in the 1940s were demonstrated as improved cheongsam, fashion clothes and western-style clothes. Population in Shanghai had a dramatic growth due to the anti-Japanese war. It, for a time, increased the demand for fashion clothes and prospered the industry of women's fashion clothes in Shanghai. At that time, Huaihai Road and Fuzhou Road were equipped with lots of women's clothes stores.

The production, texture and design of women's clothes in Shanghai were all westernized. Yet, because of the war, women's clothes in Shanghai was restricted in further development. So, the clothes in this period was featured as minor adaption of that in the 1930s and much application of western style.

\section{CONCLUSION}

Shanghai women's fashion clothes in Minguo era is of great value in research. Minguo era (1912-1949) is a crucial period in Chinese modern history; Shanghai, in terms of geological significance, was in the center of cultural communication between China and the West. Women played a vital role in saving the country and prospering the nation with a series of advanced reforms; clothes, in people's daily life, were a symbol of spirits and dynamics. These four elements are integrated in this research and lead to the finding that in certain context Shanghai women's clothes in Minguo era has been arrived at the highest level in history in terms of consumption, innovation, promotion and reception.

In this period, there were lots of modern women in Shanghai and people in all circles had a passion for fashion; thus, fashion clothes obtained amounts of consumers and became the basis of a prosperous industry of women's fashion clothes in Minguo era. What is more, fashion holders were dressed in different styles with different functions according to different occasions, time and places. Shanghai women's clothes in Shanghai is of great value in research, providing invaluable suggestions for contemporary fashion design in China, contributing to the inheritance of traditional culture and the innovation of today's clothes. Shanghai-style culture was developed further in Minguo ear, which also inspires the construction of regional culture in today's Shanghai.

\section{REFERENCES}

[1] Leo Lee. Modern Shanghai-A New Urban Culture in China (19301945). Shanghai: Shanghai Joint Publishing Company, 2008.

[2] Marie Claire Bergere, translated by Wang Ju \& Zhao Nianguo. History of Shanghai. Shanghai: Shanghai Academy of Social Sciences Press,2005.

[3] Christian Henriot, translated by Zhang Peide. Shanghai, 1927-1937, Municipal Power, Locality, and Modernization. Shanghai: Shanghai Classics Publishing House, 2004.

[4] Lu Hanchao. Beyond the Neon Lights: Everyday Shanghai in the Early Twentieth Century. Shanghai: Shanghai Classics Publishing House, 2004

[5] Xin Ping. Discovering History from Shanghai-Citizens and Social Life in the Process of Modernization (1927-1937). Shanghai: Shanghai People's Publishing House, 1996.

[6] Wu Hao. Women's Clothes and Revolution in China (1911-1935). Shanghai: Orient Publishing Center, 2008. 